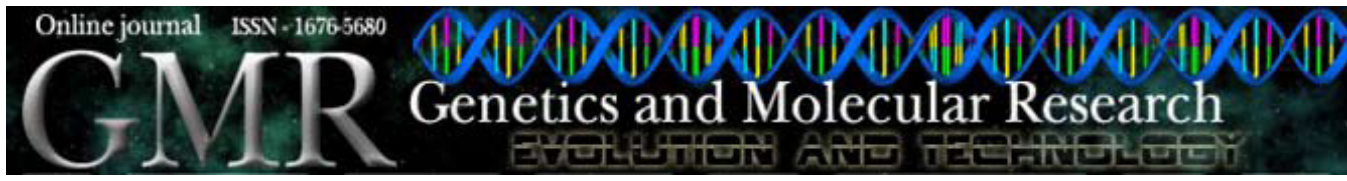

\title{
Genetic diversity in the Pantaneiro horse breed assessed using microsatellite DNA markers
}

\author{
E.H. Giacomoni ${ }^{1}$, G.P. Fernández-Stolz ${ }^{1}$ and T.R.O. Freitas ${ }^{1,2}$ \\ ${ }^{1}$ Programa de Pós-Graduação em Genética e Biologia Molecular, \\ Universidade Federal do Rio Grande do Sul, Instituto de Biociências, \\ Porto Alegre, RS, Brasil \\ ${ }^{2}$ Departamento de Genética, Universidade Federal do Rio Grande do Sul, \\ Porto Alegre, RS, Brasil \\ Corresponding author: E.H. Giacomoni \\ E-mail: elise.giacomoni@ufrgs.br
}

Genet. Mol. Res. 7 (1): 261-270 (2008)

Received July 18, 2007

Accepted January 24, 2008

Published March 18, 2008

\begin{abstract}
The genetic variability for a sample of 227 animals from three populations of Pantaneiro horses was estimated using data from 10 microsatellite loci. The number of alleles and the proportion of heterozygosity indicated high variability. A total of 91 alleles were found, with a significantly high mean number of alleles. The mean polymorphic information content was 0.7 and the paternity exclusion probability was $99.3 \%$. The inbreeding coefficient $\left(F_{\text {IS }}\right)$ was low for the three populations: Ipiranga $\left(F_{\text {IS }}=0.147\right)$, Nova Esperança $\left(F_{\text {IS }}=0.094\right)$ and Promissão $\left(F_{\text {IS }}\right.$ $=0.108)$. Genetic differentiation among all three populations was low $\left(F_{\mathrm{ST}}\right.$ $=0.008$ to 0.064$)$. Three methods were used to test for a recent bottleneck effect. The graphical method and the Wilcoxon test using the stepwise mutation model showed no bottleneck pattern for any of the populations. The test by two-phase mutation model showed genetic signatures of bottleneck for Ipiranga and Promissão. When we consider standard deviation value for Nova Esperança, the $M$-statistic detected a bottleneck pattern, but this result could be explained by a sample size effect. Therefore, there is no immediate cause for concern regarding loss of variation within the breed.
\end{abstract}

Key words: Genetic variability; Horse; Pantaneiro horses;

Microsatellites 


\section{INTRODUCTION}

Domestic animals are products of selection, improvement and domestication processes (Santos et al., 2003). The selection pressure to which they are submitted has forced races and domestic populations to adapt to specific ecological niches. These breeds have also undergone the effects of genetic drift, mutation and artificial selection (Santos et al., 2003). Therefore, the preservation and conservation of these breeds are of significant value for nature and for humans. Over the years, concerns regarding many native breeds have increased, because many of them are disappearing due to mixing and replacement. The domesticated breeds are part of biodiversity, belong to peculiar ecosystems and are tolerant to diseases. Appropriate management, conservation in development programs, and biological and local research are some ways to preserve these local breeds, in order to maintain their genetic characteristics as part of a breeding system.

The Pantaneiro breed of horses originated from Iberian horses and were brought by Europeans (Santos et al., 2000) to Brazil during its colonial period. The local Amerindians played an important role in the establishment of this breed in the Pantanal (Figure 1) (Santos et al., 1992). Since then, the Pantaneiro horses have been exposed to 500 years of natural selection, developing traits that allowed them to adapt to the Pantanal environment, i.e., to live in flooded areas during the seven-month rainy season (Miserani et al., 2002). The breeding system varies from extensive to semi-extensive (Santos et al., 2004).

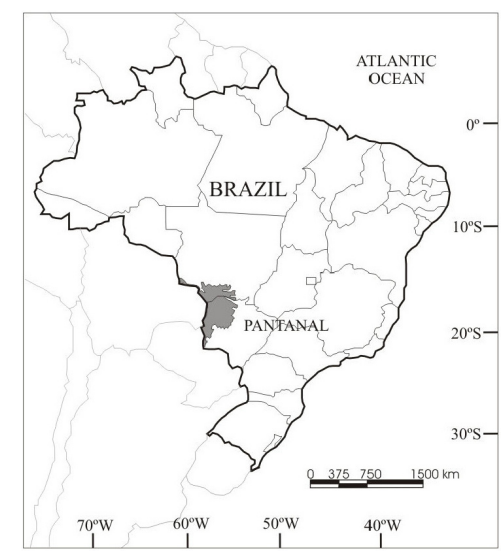

Figure 1. The entire distribution area of Pantaneiro horses in the Pantanal (gray area) in Brazil.

The Food and Agriculture Organization of the United Nations (www.fao.org/dad-is) has cited the Pantaneiro horse as an endangered breed. The crossing with other races and diseases such as trypanosomiasis and equine infectious anemia (Cothran et al., 1998) have contributed to a significant reduction in the number of these animals.

Microsatellite DNA has been used for studies of genetic variability and population structure in horse breeds (Jordana et al., 1999; Cañon et al., 2000; Baumung et al., 2004). Also, microsatellites have been recommended for routine paternity tests (Galov et al., 2005). Genetic characterization is the first step in the conservation of breeds, and in the determination of future breeding strategies (Solis et al., 2005).

Few genetic studies of Pantaneiro horses have been published, especially about genetic markers. Therefore, the goal of the present study was to analyze the genetic variability of Pantaneiro horses and to assess whether any bottleneck patterns exist.

Genetics and Molecular Research 7 (1): 261-270 (2008) www.funpecrp.com.br 


\section{MATERIAL AND METHODS}

\section{Sample collection}

Blood samples were collected from 227 individuals at three ranchs: Fazendas Ipiranga $(\mathrm{N}=126)$, Nova Esperança $(\mathrm{N}=14)$ and Promissão $(\mathrm{N}=87)$, located in the municipal district of Poconé (Mato Grosso State, Brazil). DNA was extracted following Medrano et al. (1990) and stored at $-20^{\circ} \mathrm{C}$.

\section{Microsatellites}

Ten loci of microsatellites were used in this study: VHL150 (van Haeringen et al., 1998); VHL20 (van Haeringen et al., 1994); AHT17, AHT20 (Swinburne et al., 1997); HMS02, HMS06, HMS07 (Guérin et al., 1994); HTG04, HTG06, and HTG08 (Ellegren et al., 1992). The criteria used to select these loci were the high level of heterozygosity, large number of alleles and easy amplification. However, because of problems with amplification, locus AHT20 was not included in the analysis of the results for Fazenda Nova Esperança. PCR was performed in a $15-\mu \mathrm{L}$ volume containing $50 \mathrm{ng}$ genomic DNA, $1.5 \mathrm{mM} \mathrm{MgCl}, 1$ U Taq DNA polymerase, and $200 \mu \mathrm{M}$ dNTPs. The DNA was initially denatured at $95^{\circ} \mathrm{C}$ for $10 \mathrm{~min}$, followed by 30 cycles at $94^{\circ} \mathrm{C}$ for $1 \mathrm{~min}, 55^{\circ}$ to $60^{\circ} \mathrm{C}$ for $30 \mathrm{~s}$, and $72^{\circ} \mathrm{C}$ for $1 \mathrm{~min}$. The sizes of DNA fragments were determined using a 25-bp ladder (Invitrogen) as molecular weight marker. PCR products were separated by electrophoresis on $6 \%$ gels under denaturing conditions, followed by silver staining according to the procedure of Bassam et al. (1991).

\section{Statistical analysis}

Genetic diversity within each of the three populations was measured as the number of alleles per locus $(n)$, observed heterozygosity $(\mathrm{Ho})$ and the heterozygosity expected $(\mathrm{He})$ from HardyWeinberg proportions (Nei, 1978). The mean number of alleles per locus was calculated using the AGARst program (Harley, 2001). The observed and expected heterozygosity per locus and in each population were estimated using the statistics program Arlequin 3.0 (Excoffier et al., 2005).

Genetic differentiation among and within the populations of Pantaneiros was estimated based on unbiased $F$-statistics according to Weir and Cockerham (1984), using the Fstat 2.9.3 program (Goudet, 2001). Significance levels $(\mathrm{P}=0.05)$ were corrected for simultaneous comparisons with the sequential Bonferroni test (Rice, 1989). The allelic frequencies, polymorphic information content $(P I C)$ for each microsatellite and the average paternity exclusion $(P E)$ probabilities were estimated using the Cervus 3.0 program (Marshall et al., 1998).

In order to detect genetic signatures of bottlenecks, three methods based on changes in allele frequencies were used. The first is a graphical method that tests a deficit in rare alleles in a sample of loci (Luikart et al., 1998a,b), based on the shape of the allele frequency distribution curve. An L-shaped distribution is expected under mutation-drift distribution. Bottlenecks cause a characteristic change in the distribution of allele frequencies: loss of low-frequency alleles and increase in relative abundance of intermediate and high-frequency alleles. The alleles were grouped into ten frequency classes $(0-0.10,0.11-0.2$ and so on until $0.91-1.0)$. The second method tests for excess of heterozygosity compared to the values expected from the observed number of alleles at

Genetics and Molecular Research 7 (1): 261-270 (2008) www.funpecrp.com.br 
each locus and population, assuming mutation-drift equilibrium. Significant departures from this equilibrium were identified using the Wilcoxon signed-ranks test as implemented by the program Bottleneck (Cornuet and Luikart, 1996). The computations were based on both stepwise mutation (SMM) and two-phase mutation (TPM) models (Di Rienzo et al., 1994). The third method, the mean of the ratio of number of alleles to range of allele sizes $(M)$, was described by Garza and Williamson (2001). For bottleneck populations, the allele number is expected to be reduced more quickly than the range of allele size, leading to reduced values of $M$. The $M$ values were calculated using the AGARst program (Harley, 2001). The critical value used was that proposed by Garza and Williamson (2001), where values of $M$ less than 0.68 characterize a bottleneck population.

A Bayesian MCMC approach was used in order to examine the distinctiveness of populations and the clustering of individual genotypes using the program Structure (Pritchard et al., 2000).

\section{RESULTS}

\section{Genetic variability}

The number of alleles per locus, the length of fragments, Ho and He, PIC value, and probability of $P E$ are shown in Table 1. A total of 91 alleles were obtained from the ten polymorphic loci analyzed, with the mean number of alleles per locus of 9.1. The number of alleles per marker ranged from 6 for AHT20 and HMS06 to 13 for VHL20, AHT17 and HTG06, the across-loci Ho value ranged from 0.403 for AHT20 to 0.888 for AHT17, and the He ranged from 0.519 for AHT20 to 0.880 for VHL20.

The PIC values found in ten loci ranged from 0.476 in AHT20 to 0.866 in VHL20, with all loci being highly informative (Botstein et al., 1980) and the mean $P I C$ value $=0.706$ (Table 1).

The probability of $P E$ by locus ranged from 0.146 for AHT20 to 0.604 for VHL20, and for the complete microsatellite dataset the probability of $P E$ was 0.993 (Table 1).

\begin{tabular}{|c|c|c|c|c|c|c|c|}
\hline Locus & $\mathrm{N}$ & $n$ & Size range & Ho & $\mathrm{He}$ & $P I C$ & $P E$ \\
\hline VHL150 & 223 & 7 & $92-104$ & 0.619 & 0.623 & 0.575 & 0.215 \\
\hline VHL20 & 180 & 13 & 85-109 & 0.733 & 0.880 & 0.866 & 0.604 \\
\hline AHT17 & 152 & 13 & $111-135$ & 0.888 & 0.869 & 0.853 & 0.581 \\
\hline AHT20 & 77 & 6 & $125-135$ & 0.403 & 0.519 & 0.476 & 0.146 \\
\hline HMS02 & 152 & 7 & $220-236$ & 0.724 & 0.708 & 0.670 & 0.304 \\
\hline HMS06 & 197 & 6 & $163-173$ & 0.462 & 0.706 & 0.656 & 0.287 \\
\hline HMS07 & 159 & 7 & $172-184$ & 0.440 & 0.711 & 0.664 & 0.304 \\
\hline HTG04 & 207 & 9 & $125-141$ & 0.715 & 0.833 & 0.811 & 0.496 \\
\hline HTG06 & 188 & 13 & 82-106 & 0.676 & 0.709 & 0.666 & 0.310 \\
\hline HTG08 & 139 & 10 & 178-196 & 0.626 & 0.845 & 0.823 & 0.519 \\
\hline Mean & & 9. & & 0.628 & 0.740 & 0.706 & 0.993 \\
\hline
\end{tabular}

Number of animals tested $(\mathrm{N})$, number of alleles per locus $(n)$, size range (bp, base pairs), observed heterozygosity $(\mathrm{Ho})$, expected heterozygosity $(\mathrm{He})$, polymorphism information content $(\mathrm{PIC})$, probability of paternity exclusion $(P E)$.

The population that showed the highest allelic variability was Ipiranga with 82 alleles (an average of 8.2 alleles per locus). Horses at the Nova Esperança Ranch showed the smallest number of alleles, with an average of 4.9 alleles per locus. The loci with the highest number of alleles in the Ipiranga herd were VHL20 and AHT17 with 13 alleles. In the Nova Esperança

Genetics and Molecular Research 7 (1): 261-270 (2008) www.funpecrp.com.br 
herd, the locus with the highest number of alleles was VHL20 (8), and in the Promissão herd it was HTG06 with 12 alleles (Table 2).

Table 2. Microsatellite genetic variation in three populations of Pantaneiro horses.

\begin{tabular}{|c|c|c|c|c|c|c|}
\hline Population & Locus & $n$ & Ho & $\mathrm{He}$ & $F_{\text {IS }}$ & Gene diversity \\
\hline \multicolumn{7}{|c|}{ Ipiranga $(\mathrm{N}=126)$} \\
\hline & VHL150 & 5 & 0.645 & 0.641 & -0.006 & 0.641 \\
\hline & VHL20 & 13 & 0.761 & 0.861 & 0.116 & 0.861 \\
\hline & AHT17 & 13 & 0.873 & 0.869 & -0.007 & 0.868 \\
\hline & AHT20 & 4 & 0.352 & 0.462 & 0.215 & 0.450 \\
\hline & HMS02 & 7 & 0.810 & $0.783^{*}$ & -0.042 & 0.778 \\
\hline & HMS06 & 6 & 0.527 & $0.733^{*}$ & 0.279 & 0.732 \\
\hline & HMS07 & 6 & 0.431 & $0.730^{*}$ & 0.410 & 0.732 \\
\hline & HTG04 & 9 & 0.618 & $0.819^{*}$ & 0.242 & 0.816 \\
\hline & HTG06 & 10 & 0.627 & $0.647^{*}$ & 0.027 & 0.645 \\
\hline & HTG08 & 9 & 0.629 & $0.845^{*}$ & 0.249 & 0.839 \\
\hline & Total & 82 & 0.627 & 0.739 & 0.147 & - \\
\hline & Mean & 8.2 & & & & \\
\hline \multicolumn{7}{|c|}{ Nova Esperança $(\mathrm{N}=14)$} \\
\hline & VHL150 & 4 & 0.461 & 0.403 & -0.152 & 0.401 \\
\hline & VHL20 & 8 & 0.615 & 0.886 & 0.302 & 0.881 \\
\hline & AHT17 & 6 & 0.857 & 0.835 & -0.029 & 0.883 \\
\hline & AHT20 & NA & NA & NA & NA & NA \\
\hline & HMS02 & 3 & 0.600 & 0.484 & -0.256 & 0.478 \\
\hline & HMS06 & 5 & 0.461 & $0.673^{*}$ & 0.269 & 0.631 \\
\hline & HMS07 & 3 & 0.375 & 0.441 & -0.105 & 0.339 \\
\hline & HTG04 & 4 & 0.428 & 0.521 & 0.183 & 0.525 \\
\hline & HTG06 & 5 & 0.538 & 0.710 & 0.211 & 0.683 \\
\hline & HTG08 & 6 & 0.600 & 0.673 & 0.115 & 0.678 \\
\hline & Total & 44 & 0.493 & 0.562 & 0.094 & - \\
\hline & Mean & 4.9 & & & & \\
\hline \multicolumn{7}{|c|}{ Promissão (N = 87) } \\
\hline & VHL150 & 7 & 0.604 & $0.605^{*}$ & 0.002 & 0.606 \\
\hline & VHL20 & 11 & 0.706 & $0.891 *$ & 0.209 & 0.893 \\
\hline & AHT17 & 11 & 0.928 & 0.851 & -0.091 & 0.851 \\
\hline & АHT20 & 6 & 0.777 & 0.836 & 0.074 & 0.840 \\
\hline & HMS02 & 5 & 0.647 & 0.621 & -0.041 & 0.622 \\
\hline & HMS06 & 4 & 0.368 & $0.674 *$ & 0.455 & 0.676 \\
\hline & HMS07 & 6 & 0.464 & $0.695^{*}$ & 0.333 & 0.696 \\
\hline & HTG04 & 9 & 0.920 & $0.848 *$ & -0.085 & 0.848 \\
\hline & HTG06 & 12 & 0.767 & $0.773^{*}$ & 0.003 & 0.770 \\
\hline & HTG08 & 7 & 0.625 & $0.837^{*}$ & 0.249 & 0.832 \\
\hline & Total & 78 & 0.680 & 0.763 & 0.108 & - \\
\hline & Mean & 7.8 & & & & \\
\hline
\end{tabular}

*P $<0.05$ after Bonferroni correction for multiple tests. Number of alleles per locus $(n)$, observed heterozygosity $(\mathrm{Ho})$, expected heterozygosity $(\mathrm{He})$, inbreeding coefficient values $\left(F_{\mathrm{IS}}\right)$, and gene diversity (Nei, 1978) per population. N, sample size; NA, not available.

A total of 11 exclusive alleles were observed at Ipiranga, only 1 exclusive allele at Nova Esperança, and 8 at Promissão. The allelic richness $(A)$, calculated as the mean number of alleles per locus per population, was lowest for the Nova Esperança herd (Table 2).

The $\mathrm{He}$ values for each locus ranged from 0.403 for VHL150 at Nova Esperança to 0.891 for VHL20 at Promissão. The Ho values ranged from 0.352 for AHT20 at Ipiranga to 0.928 for AHT17 at Promissão. Values of $H o$ for each population for all the loci examined were 
$0.352 \leq H o \leq 0.873$ for Ipiranga, $0.375 \leq H o \leq 0.857$ for Nova Esperança and $0.368 \leq H o \leq$ 0.928 for Promissão (Table 2).

Six loci at Ipiranga and seven at Promissão showed significant deviations from the genotype proportion expected according to the Hardy-Weinberg equilibrium after the Bonferroni correction for multiple tests $(\mathrm{P}<0.005$; Table 2). Only one locus (HMS06) for Nova Esperança showed significant deviations according to the Hardy-Weinberg equilibrium. AHT20 was not assessed.

The inbreeding coefficients $\left(F_{\text {IS }}\right)$ estimated according to Weir and Cockerham (1984) are shown in Table 2 . The results showed a lower value for Ipiranga $\left(F_{\text {IS }}=0.147 ; \mathrm{P}=0.0017\right)$ than for Promissão $\left(F_{\mathrm{IS}}=0.108 ; \mathrm{P}=0.0617\right)$ and Nova Esperança $\left(F_{\mathrm{IS}}=0.094 ; \mathrm{P}=0.0017\right)$; however, values for Ipiranga and Promissão were significantly different from zero, even after $\alpha$ levels were corrected for multiple tests $(\alpha=0.0016)$.

\section{Genetic differentiation and bottleneck effects}

Low genetic differentiation among populations was found, with pairwise $F_{\mathrm{ST}}$ coefficients ranging from 0.008 between Nova Esperança and Promissão to 0.064 between Ipiranga and Nova Esperança (Table 3). Using a Bayesian MCMC approach and considering a range of one to three potential populations (Figure 2 ), the probability value obtained for three populations ( $K=3$, mean value of $\ln$ likelihood $=-5257.9 \pm 33.4)$ was higher than for two $(K=2$, mean value of $\ln$ likelihood $=-5409.0 \pm 16.9)$ and one population $(K=1$, mean value of $\ln$ likelihood $=-623.6 \pm 6.3)$.

Table 3. Population differentiation among Pantaneiro horse populations based on 10 microsatellite loci.

\begin{tabular}{lccc}
\hline & Ipiranga & Nova Esperança & Promissão \\
\hline Ipiranga & - & 1.436 & 1.509 \\
Nova Esperança & 0.064 & - & 1.140 \\
Promissão & 0.019 & $0.008^{*}$ & - \\
\hline
\end{tabular}

*P $<0.016$. The $F_{\mathrm{ST}}$ values are shown below the diagonal, while the number of effective migrants per generation are shown above the diagonal.

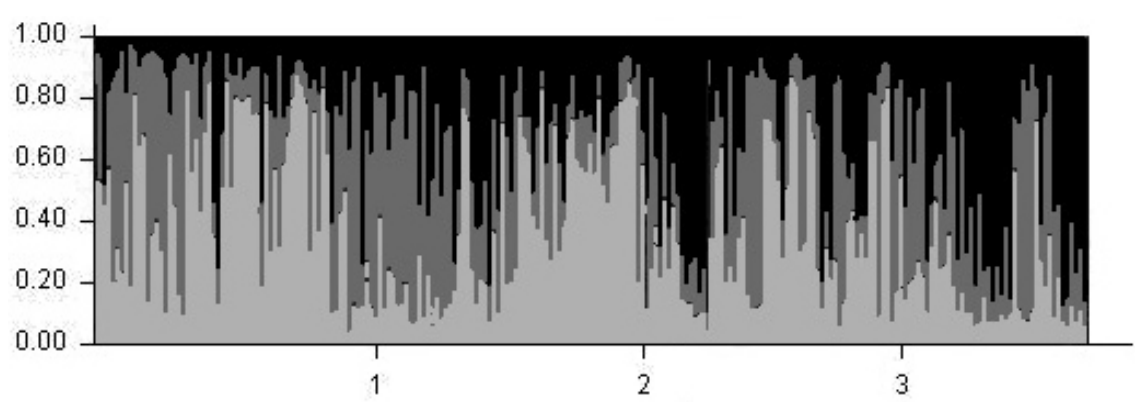

Figure 2. Plot of estimates of $Q$ for the more probable scenario $K=3$ (mean value of $\ln$ likelihood $=-5257.9 \pm 33.4$ ) than $K=2(-5409.0 \pm 16.9)$ or $K=1(-5623.6 \pm 6.3)$. Each individual is represented by a single vertical line broken into $K$ colored segments, with lengths proportional to each of the $K$ inferred clusters.

Because the Bottleneck computer program detects bottlenecks within the last 12 to 15 generations and considering that the minimum generation interval in horses is eight years (Ollivier, 1999), 12 to 15 generations would represent the last 96 to 120 years. The distribution

Genetics and Molecular Research 7 (1): 261-270 (2008) www.funpecrp.com.br 
of allele frequencies for the three populations showed no differences from the expected L-shaped patterns observed in stable populations (Figure 3 ). The test for excess heterozygosity produced non-significant P values based on the SMM. However, the test based on the TPM produced significant P values for Ipiranga and Promissão. Genetic signatures of bottlenecks from Garza and Williamson's $M$ were only marginally observed for Nova Esperança, with an $M$ value higher than the critical value (0.68) but with a high $\mathrm{SD}$ value $\left(\mathrm{M}_{\mathrm{Pop} 2}=0.71 \pm 0.21\right)$ (Table 4).

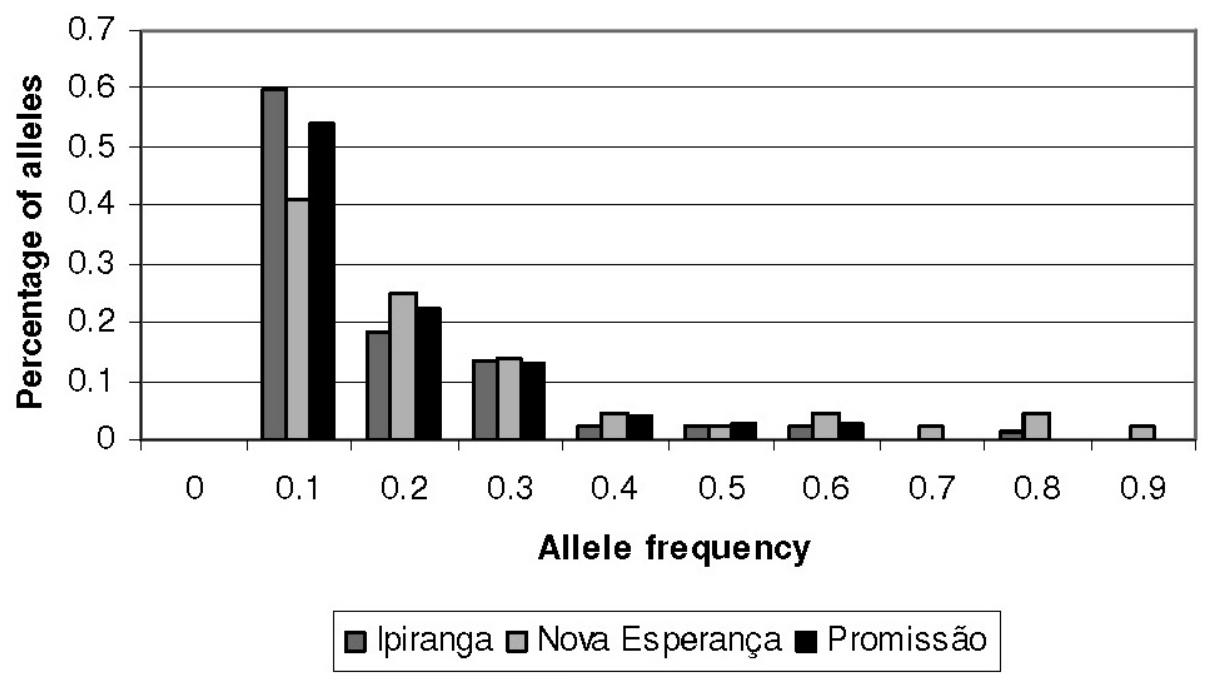

Figure 3. Allele frequency distribution in the three populations of Pantaneiro horses sampled. The bars represent the proportion of all alleles detected in each allele frequency class calculated for Ipiranga $(\mathrm{N}=126)$, Nova Esperança $(\mathrm{N}=$ 14) and Promissão $(\mathrm{N}=87)$. No deviations from the L-shaped pattern were observed, indicating a lack of a bottleneck in these populations.

Table 4. Results of the bottleneck detection tests for three Pantaneiro horse populations.

\begin{tabular}{llll}
\hline & \multicolumn{2}{c}{ Wilcoxon test } & $M$ values \\
\cline { 2 - 3 } & SMM & TPM & \\
\hline Ipiranga & 0.75 & $0.05^{*}$ & $0.94 \pm 0.08$ \\
Nova Esperança & 0.99 & 0.97 & $0.71 \pm 0.21$ \\
Promissão & 0.42 & $0.04^{*}$ & $0.96 \pm 0.12$ \\
\hline
\end{tabular}

*P $<0.05$. The Wilcoxon test was applied to the stepwise mutation model (SMM) and to the two-phase mutation model (TPM). $M$ is Garza and Williamson's parameter (mean $\pm \mathrm{SD}$, across all loci).

\section{DISCUSSION}

Few genetic studies have been performed on Pantaneiro horses. Cothran et al. (1998) used seven blood-group loci and ten biochemical genetic loci in Pantaneiro horses to compare them to other domestic horse breeds. Analysis of genetic relationships showed that there is no immediate concern regarding loss of variation within the Pantaneiro. Fuck (2002) used 13 RAPD loci to characterize this breed, and the results showed differences within populations. A morphological study by Miserani (2001) with animals from the Brazilian States Mato Grosso 
and Mato Grosso do Sul showed little morphological variation, i.e., phenotypic uniformity.

Although Pantaneiro horses live exclusively in the central-western region of Brazil, levels of microsatellite variability were high compared with other equine breeds. We detected 91 alleles for 10 polymorphic loci, thus a mean of 9.1 per locus. The mean numbers of alleles per locus reported for other breeds are: 7.06 (range 3-77) for Lipizzaner horses (Achmann et al., 2004), 10.58 (range 6-14) for Mediterranean horse breeds (Marletta et al., 2006), 10.41 (range 7-13) for Portuguese horse breeds (Luís et al., 2007), and 6.0 (range 5-12) for Spanish Trotter horses (Azor et al., 2007).

When the herd from each ranch was analyzed separately, differences were observed with respect to allelic richness. Ipiranga (8.2) and Promissão (7.8) showed higher mean numbers of alleles than Nova Esperança (4.9), which showed low allelic diversity, probably because of the small number of samples taken there.

Individual $P I C$ values were highly correlated with the effective number of alleles detected for each corresponding locus. AHT20 showed low variability and PIC values, and VHL20 and AHT17 showed high variability and the highest values of PIC.

Using 10 microsatellite loci, we found a global $P E$ value of $99.3 \%$ for the three populations. All loci contributed to the $P E$ value. This result is similar to those reported by Galov et al. (2005) in Lipizzaners (99.5\%) and by Luís et al. (2002) in Lusitano and Garrano horses (99.6 and 99.5\%, respectively). The high $P E$ value indicates that the microsatellites for horses are appropriate for a routine parentage test for Pantaneiro horse populations.

The data obtained indicate that the three herds of Pantaneiro horses show high levels of heterozygosity ( 0.628 ; Table 1$)$. Published reports of polymorphisms with microsatellites in other equine breeds range from 0.610 for the Zanskari horse breed (Behl et al., 2006), 0.663 in Lipizzaners (Achmann et al., 2004), 0.647 for Spanish Trotters (Azor et al., 2007), 0.745 for Garranos, and 0.677 for Lusitanos (Luís et al., 2002).

Considering that the Pantaneiro breed is found only in the Pantanal region and these animals are adapted to this region, the population coefficients showed low values of $F_{\text {IS }}$ and $F_{\mathrm{ST}}$, which indicate a low rate of inbreeding and high gene flow among the farms. These results suggest that local breeding management is responsible for this variation.

To test for a recent bottleneck effect, three methods were used. The graphical method and the Wilcoxon test using the SMM showed no bottleneck pattern for any of the three populations. However, for the Wilcoxon signed-ranks test by TPM, Ipiranga and Promissão showed genetic signatures of bottleneck. Also, when we consider SD value for Nova Esperança, the $M$ statistic detected a bottleneck pattern. These could suggest a possible recent effect, but may be explained by the small size of the sample from this population.

In addition to the present high genetic variability, which allows us to be more optimistic regarding the breed's vulnerability to extinction, there are several other reasons to conserve it. First, it is economically important, being the means of transportation and locomotion for many native people in the Pantanal. Second, the Pantaneiro horse has a distinct historic and cultural value for the people of Pantanal. Third, the scientific value of the breed is high because it carries genetic information since the colonization period and has acquired specific characteristics that if lost could not be regained.

Our results indicate no grounds for immediate concern with respect to loss of variation within breed. This study contributes to the practical understanding of the genetic variability of the Pantaneiro horse.

Genetics and Molecular Research 7 (1): 261-270 (2008) www.funpecrp.com.br 


\section{ACKNOWLEDGMENTS}

The authors thank the Associação Brasileira de Criadores de Cavalos Pantaneiros (ABCCP), Sr. João Losada of the Fazenda Ipiranga, Srs. Paulo and Vítor Moura of the Fazenda Promissão and Sr. Hilton Figueiredo Aguiar of the Fazenda Nova Esperança. We would also like to thank Rodrigo Fornel for the map of the Pantanal. Research supported by CNPq.

\section{REFERENCES}

Achmann R, Curik I, Dove P, Kavar T, et al. (2004). Microsatellite diversity, population subdivision and gene flow in the Lipizzan horse. Anim. Genet. 35: 285-292.

Azor P, Valera M, Gómez M, Goyache F, et al. (2007). Genetic characterization of the Spanish Trotter horse breed using microsatellite markers. Genet. Mol. Biol. 30: 37-42.

Bassam BJ, Caetano-Anollés G and Gresshoff PM (1991). Fast and sensitive silver staining of DNA in polyacrylamide gels. Anal. Biochem. 196: 80-83.

Baumung R, Simianer H and Hoffmann I (2004). Genetic diversity studies in farm animals - a survey. J. Anim. Breed. Genet. 121: 361-373.

Behl R, Behl J, Gupta N, Gupta SC, et al. (2006). Genetic characterization of Zanskari breed of horse. J. Genet. 85: 199-203.

Botstein D, White RL, Skolnick M and Davis RW (1980). Construction of a genetic linkage map in man using restriction fragment length polymorphisms. Am. J. Hum. Genet. 32: 314-331.

Cañon J, Checa ML, Carleos C, Vega-Pla JL, et al. (2000). The genetic structure of Spanish Celtic horse breeds inferred from microsatellite data. Anim. Genet. 31: 39-48.

Cornuet JM and Luikart G (1996). Description and power analysis of two tests for detecting recent population bottlenecks from allele frequency data. Genetics 144: 2001-2014.

Cothran E, Santos S, Mazza M, Lear T, et al. (1998). Genetics of the Pantaneiro horse of the Pantanal region of Brazil. Genet. Mol. Biol. 21: 343-349.

Di Rienzo A, Peterson AC, Garza JC, Valdes AM, et al. (1994). Mutational processes of simple-sequence repeat loci in human populations. Proc. Natl. Acad. Sci. USA 91: 3166-3170.

Ellegren H, Johansson M, Sandberg K and Andersson L (1992). Cloning of highly polymorphic microsatellites in the horse. Anim. Genet. 23: 133-142.

Excoffier L, Laval G and Schneider S (2005). Arlequin version 3.0: an integrated software package for population genetics data analysis. Evol. Bioinformatics Online 1: 47-50.

Fuck B (2002). Caracterização genética do cavalo pantaneiro: uma contribuição para a conservação da raça. Dissertação de Mestrado em Ciências Agrárias. Faculdade de Agronomia e Medicina Veterinária, Universidade de Brasília, Brasília.

Galov A, Byrne K, Duras-Gomereie, Gomereie T, et al. (2005). Effectiveness of nine polymorphic microsatellite markers in parentage testing in Posavina, Croatian Coldblood and Lipizzaner horse breeds in Croatia. Livest. Prod. Sci. 93: $277-282$.

Garza JC and Williamson EG (2001). Detection of reduction in population size using data from microsatellite loci. Mol. Ecol. 10: 305-318.

Goudet J (2001). FSTAT, a program to estimate and test gene diversities and fixation indices. Version 2.9.3. Available at http://www.unil.ch/izea/softtwares/fstat.html. Updated from Goudet (1995). Accessed January 20, 2007.

Guérin G, Bertaud M and Amigues Y (1994). Characterization of seven new horse microsatellites: HMS1, HMS2, HMS3, HMS5, HMS6, HMS7 and HMS8. Anim. Genet. 25: 62.

Harley EH (2001). AGARst. A program for calculating allele frequencies, Gst and Rst from microsatellite data. Version 2.0. University of Cape Town, Cape Town.

Jordana J, Folch P and Sanchez A (1999). Genetic variation (protein markers and microsatellites) in endangered Catalonian donkeys. Biochem. Syst. Ecol. 27: 791-798.

Luikart G, Allendorf FW, Cornuet JM and Sherwin WB (1998a). Distortion of allele frequency distributions provides a test for recent population bottlenecks. J. Hered. 89: 238-247.

Luikart G, Sherwin WB, Steele BM and Allendorf FW (1998b). Usefulness of molecular markers for detecting population bottlenecks via monitoring genetic change. Mol. Ecol. 7: 963-974.

Luís C, Cothran E and Oom M (2002). Microsatellites in Portuguese autochthonous horse breeds: usefulness for parentage testing. Genet. Mol. Biol. 25: 131-134.

Luís C, Juras R, Oom MM and Cothran EG (2007). Genetic diversity and relationships of Portuguese and other horse

Genetics and Molecular Research 7 (1): 261-270 (2008) www.funpecrp.com.br 
breeds based on protein and microsatellite loci variation. Anim. Genet. 38: 20-27.

Marletta D, Tupac-Yupanqui I, Bordonaro S, Garcia D, et al. (2006). Analysis of genetic diversity and the determination of relationships among western Mediterranean horse breeds using microsatellite markers. J. Anim. Breed. Genet. 123: $315-325$.

Marshall TC, Slate J, Kruuk LE and Pemberton JM (1998). Statistical confidence for likelihood-based paternity inference in natural populations. Mol. Ecol. 7: 639-655.

Medrano JF, Aasen E and Sharrow L (1990). DNA extraction from nucleated red blood cells. Biotechniques 8: 43.

Miserani M, McManus C, Abreu U, Santos S, et al. (2001). Fatores que influem nas características lineares do cavalo pantaneiro. In: $38^{a}$ Reunião Anual da Sociedade Brasileira de Zootecnia. Fealq/Sociedade Brasileira de Zootecnia, Piracicaba, 551-552.

Miserani M, McManus C, Santos A, Silva J, et al. (2002). Evaluation of the factors which influence linear measurements of the Pantaneiro Horse. Rev. Bras. Zootec. 31: 335-341.

Nei M (1978). Estimation of average heterozygosity and genetic distance from a small number of individuals. Genetics 89: 583-590.

Ollivier L (1999). Situation and justification of the conservation of animal genetics resources in Europe. Naturzale 14: $17-27$.

Pritchard JK, Stephens M and Donnelly P (2000). Inference of population structure using multilocus genotype data. Genetics 155: 945-959.

Rice WW (1989). Analyzing tables of statistical tests. Evolution 43: 223-225.

Santos S, Sereno J, Mazza M and Mazza C (1992). Origin of the Pantaneiro Horse in Brazil. Arch. Zootec. 41: 371-381.

Santos S, Mariante A, Abreu U and McManus C (2000). Conservation and Management of the Pantaneiro Horse in the Pantanal. In: V Global Conference in Conservation of Domestic Animal Genetic Resources. Embrapa Recursos Genéticos e Biotecnologia, Brasília, 8.

Santos S, McManus C, Mariante A, Sereno J, et al. (2003). Estratégias de conservação in situ do cavalo pantaneiro. Documentos Embrapa 29, Brasília.

Santos SA, Mazza MCM, Sereno JRB, Mazza CSA, et al. (2004). Production system of Pantaneiro Horses in the Pantanal. Arch. Zootec. 53: 333-336.

Solis A, Jugo B, Mériaux J, Iriondo M, et al. (2005). Genetic diversity within and among four South European Native Horse breeds based on microsatellite DNA analysis: implications for conservation. J. Hered. 96: 670-678.

Swinburne JE, Marti E, Breen M and Binns MM (1997). Characterization of twelve new horse microsatellite loci: AHT12AHT23. Anim. Genet. 28: 453.

van Haeringen H, Bowling AT, Stott ML, Lenstra JA, et al. (1994). A highly polymorphic horse microsatellite locus: VHL20. Anim. Genet. 25: 207.

van Haeringen WA, van de Goor LH, van den Hout N, Lenstra JA, et al. (1998). A polymorphic horse microsatellite locus: VHL150. Anim. Genet. 29: 464.

Weir B and Cockerham C (1984). Estimating F-statistics for the analysis of population structure. Evolution 38: 13581370.

Genetics and Molecular Research 7 (1): 261-270 (2008) www.funpecrp.com.br 